\title{
OPTIMIZATION OF PARAMETERS OF THE OOCYTE ENUCLEATION AND FUSION WITH THE SOMATIC CELL DURING PRODUCTION OF MAMMALIAN CLONED EMBRYOS
}

\author{
G.N. Singina ${ }^{1}$, A.V. Lopukhov', N.A. Zinovieva', E.V. Shapkanova ${ }^{2}$, A.A. Puzik ${ }^{3}$ \\ ${ }^{1}$ All-Russia Research and Development Institute for Livestock Husbandry, RAAS, Dubrovitsy settlement 142132, Moscow province, Russia \\ e-mail: gsingina@mail.ru,vubi_myaso@mail.ru,nzinovieva@mail.ru \\ ${ }^{2}$ Velikiye Luki State Agricultural Academy, Velikie Luky 182100, Pskov province, Russia \\ e-mail:lenok150185@mail.ru \\ ${ }^{3}$ Smolensk Research and Development Institute of Agriculture, RAAS, Smolensk 214025, Russia \\ e-mail:smniish@yandex.ru
}

Received January 15, 2013

S u m m ar y

Parameters of the oocyte enucleation and fusion with somatic cell for producing of cattle cloned cetohybrids were studied. It was established that the electrofusion efficiency depends on strength, duration and set number of electrical pulse. The optimal parameters for Multiporator (Eppendorf, Germany) were determined: two consistent pulses DC electrical field each of $30 \mathrm{~V}$ field strength and 15 msec duration followed by the pulse of AC electrical field of $5 \mathrm{~V}$ and $10 \mathrm{sec}$ duration. It was found that the first polar body serving as a marker for the chromosome position at «blind» enucleation must not deviate from the chromosome location by more than 10 degrees.

Keywords: in vitro culture, oocyte, cattle nuclear transfer, electrofusion, enucleation.

Somatic cloning is widely used in biomedical research and in production of transgenic animals (1). Despite a certain success of using this technique in recent years, it is yet inefficient in cattle and other domestic animals owing to high incidence of embryonic abnormalities and low viability of the born cloned offspring (2-4).

To create a clone, genetic material of the host's egg cell is replaced by genetic material of a somatic cell (reprogramming). It is often associated with complete removal of the oocyte's chromosomes at metaphase II, after which the somatic donor cell is introduced in the perivitelline space of the (5).

The procedure is visualized by staining of the chromosomes with fluorescent vital dye Hoechst 33342 allowing enucleation of the host oocyte under ultraviolet light (6). However, this approach adversely affects viability of cells and future embryos (7). The alternative solution is blind enucleation when metaphase chromosomes are recognized by location of the first polar body that serves as a reference point. This method is considered as more safe for viability of the egg cells and their capacity to future embryonic development (8), though some problems are not excluded too. After isolation of the first spindle pole body, metaphase plate of chromosomes stays for a while in a close proximity to it. Then, with aging of the egg cell, chromosomes disconnect from the spindle pole body that migrates to the perivitelline space. This circumstance complicates blind enucleation of oocytes or interdicts it (9), which necessitates identifying the factors important for efficiency of the method.

After enucleation, the fusion of cytoplast and karyoplast is performed to form a new reconstructed egg cell. Following development of cloned embryos directly depends on successful association of the host and donor cells, and viability of the resulting hybrid (10-14).

Electrofusion is commonly used technique for karyoplast-cytoplast fusion. A pulsed electric field applied to the cell membrane causes in it a reversible loss of integrity - transmembrane pores, after which the membrane becomes compressed and discharged. This makes possible the fusion of two contacting membranes, whose contact points open cytoplasmic channels for exchange of cytoplasmic colloid. As a result, one cell is formed from two, and the residual membrane material remains in it included in cytoplasmic vacuoles (15).

Electrofusion of cells can be performed by different methods depending on technical characteristics of used instruments, types of cells, and their features. The efficiency of karyoplast-cytoplast fusion depends on current voltage, duration, and frequency of the electric pulse.

The purpose of this work was studying the efficiency of blind enucleation of bovine oocytes depending on the location of spindle polar body relative to chromosomes metaphase II, as well as establishing the optimized procedure for electrofusion of enucleated oocyte and somatic cell in the pulsed electric field.

Technique. The oocyte-cumulus complexes (OCC) were derived from ovaries of cows and heifers obtained at slaughter. Transportation of the ovaries was performed in a physiological solution at $28-35{ }^{\circ} \mathrm{C}$ for $3-4$ hours. OCC were isolated by dissection of visible follicles; groups of 35-40 oocytes were cultured in modified TS199 medium containing HEPES (25 mM), Na pyruvate (1 $\mathrm{mM}$ ), fetal bovine serum (10\%), gonadotropins (LH and FSH - luteinizing hormone and follicle-stimulating hormone), and gentamicin $(50 \mathrm{ug} / \mathrm{ml})$. After $20-24 \mathrm{~h}$ of maturation, OCC were treated with $0,1 \%$ hyaluronidase solution, cumulus cells (CC) were mechanically removed, and then oocytes with the first polar body (FPB) were collected.

To evaluate the efficiency of blind enucleation depending on location of chromosomes relative to FPB, the oocytes were stained with vital fluorescent dye Hoechst 33342 and separated in groups: I group - oriented oocytes in which chromosomes were located near FPB $\left(0-5^{\circ}\right)$; II group - oocytes with FPB deviated at no more than $10^{\circ}$; III and IV groups - oocytes with FBP deviated at, respectively, $11-30^{\circ}$ and more than $31^{\circ}$. The location of FPB was determined on a fluorescent microscope (Axiovert 40 CFL, "Carl Zeiss GmbH", Germany) by measuring the angle between the lines connecting the oocyte's center with FPB and the metaphase plate. After blind enucleation, the oocytes were re-stained with Hoechst 33342 and then the completeness of removal of the genetic material was assessed using a fluorescent microscope. Donor nuclei were isolated from fetal bovine fibroblasts prepared for the transfer as previously described (16).

Oocyte enucleation and somatic cell nuclear transfer were carried out through the direct puncture in zona pellucida by $3 \mathrm{D}$ hydraulic micromanipulator with ultra-precise tuning ("Narishige", Japan); the procedure was visually controlled using the microscope Diaphot ("Nicon", Japan). Karyoplast-cytoplast fusion was carried out in multiporator ("Eppendorf”, Germany). The 
reconstructed oocytes were placed in the microchamber with a distance between electrodes 0,2 mm filled with a buffer (Eppendorf ${ }^{1}$ 4308070.536).

Two experiments were conducted in order to determine the optimum conditions for electrofusion. In the first experiment, oocytes were exposed to AC electric field ( 3 and $5 \mathrm{~V}$ ) for 5, 10, 15, 20, and 25 seconds, while the cells' drift to electrodes and orientation of contact points to electric field lines were assessed. In the second experiment, the oocytes were exposed to the AC electric field as described above, followed by one and two successive rectangular impulses of direct current $(20,25,30,35,40,45$, and $50 \mathrm{~V}$ ) with the duration of 15 and 30 microseconds. These oocytes then were briefly cultured for 2 hours in CR1aa medium (17). Resulting cells-hybrids were examined for the presence or absence of degenerative changes (compression and/or lysis of the content). The efficiency of cell fusion was determined as the rate of morphologically normal stable karyoplast-cytoplast hybrids.

The obtained data were expressed as mean percentages, which then were subject to arcsine transformation and one-way ANOVA. The significance of differences was assessed by comparison of mean values in Tukey test. Statistical processing was performed in the computer program SigmaStat. The experiments were repeated 3-fold.

Results. The efficiency of blind enucleation of bovine oocytes decreased with increasing the angle of FPB deviation from location of chromosomes (table).

The efficiency of blind enucleation of bovine oocytes depending on location of the first polar body (FPB)

\begin{tabular}{l|c|c|c|c}
\hline \multirow{2}{*}{ Group } & \multirow{2}{*}{ Angle to FPB } & \multirow{2}{*}{ Total number of oocytes, } & \multicolumn{2}{|c}{ Resulting cytoplasts } \\
\cline { 4 - 5 } & & $n$ & $n$ & $\%, X \pm x$ \\
\hline I & $0-5^{\circ}$ & 110 & 109 & $97,2 \pm 2,2$ \\
II & $6-10^{\circ}$ & 62 & 51 & $82,3 \pm 3,4$ \\
III & $11-30^{\circ}$ & 57 & 35 & $61,4 \pm 4,3$ \\
IV & $31-90^{\circ}$ & 47 & 12 & $25,5 \pm 3,5$ \\
\hline
\end{tabular}

The greatest outcome of cytoplasts was observed in Group I (oocytes with chromosomes located near FPB). In the variant of FPB deviation from metaphase II at $6^{\circ}$ and more, the efficiency of enucleation was much lower. Thus, in II, III, and IV groups, the outcome of enucleated cells was lower than in group I, respectively, by $14,9(p<0,05), 35,8$, and 71,7\% ( $p<0,001)$.

Along with it, the efficiency of karyoplast-cytoplast fusion was correlated with parameters of the applied electric field. Thus, the efficiency of oocytes' drift to electrodes and orientation of the cells' contact points relative to electric field lines depended on the voltage and duration of impulses (first experiment). In the variant with $3 \mathrm{~V}$, complete drift of the oocytes to electrodes occurred only at duration of impulses 20 and $25 \mathrm{~s}$, which though was accompanied by compression and lysis of cell contents. The optimal parameters of electric field providing the complete drift to electrodes of cattle oocytes and preservation of their quality were determined: AC impulse of $5 \mathrm{~V}$ with duration of 10 seconds. The longer duration of impact in both experiments contributed to degenerative changes in the oocytes.

In the second experiment (Fig.), the greatest outcome of hybrid cells was obtained in the case of two consecutive impulses of direct electric field of $30 \mathrm{~V}$ and duration of 15 microseconds. Further increasing the voltage to $35 \mathrm{~V}$ did not lead to positive results: the rate of karyoplast-cytoplast fusion decreased by $14,5 \%$ and amounted to $68,8 \%$ (Fig., B). The increase in duration of two consecutive impulses (Fig., D) reduced the efficiency of fusion. The increase in voltage of impulses from 25 to $40 \mathrm{~V}$ led to a smooth growth in number of hybrids with degenerative changes (from 16,6 to 80,0\%).

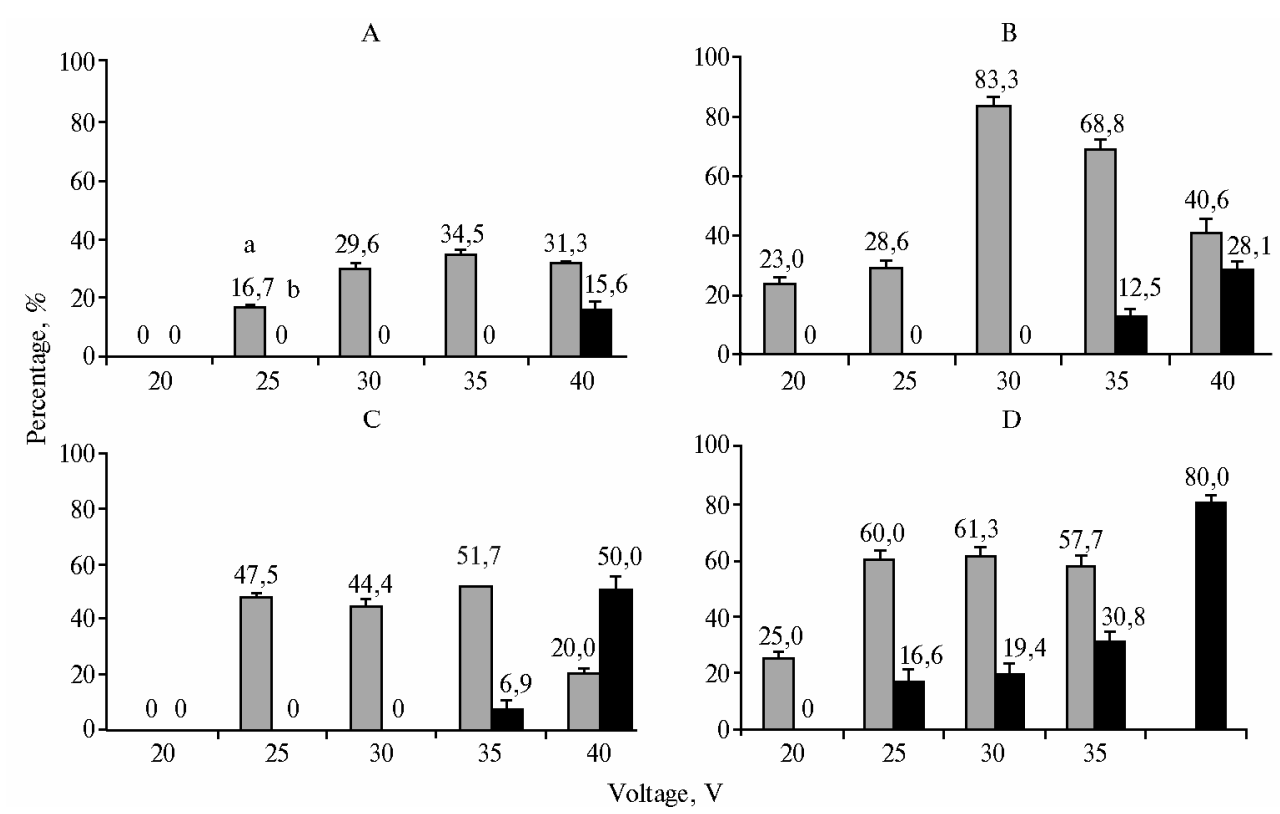

Efficiency of karyoplast-cytoplast fusion in bovine oocytes depending on voltage, number, and duration of direct current impulses: $\mathrm{A}-1$ impulse of 15 microseconds, $\mathrm{B}-2$ impulses of 15 microseconds, $\mathrm{C}-1$ impulse of 30 microseconds, D - 2 impulses of 30 microseconds; $\mathrm{a}$ - percentage of fusion, $\%, \mathrm{~b}$ - percentage of regeneration, $\%$.

Using a single electric impulse with duration of 15 microseconds didn't provide high rate of hybrids (Fig., A). A single exposure to the impulses of 25,30 , and $35 \mathrm{~V}$ for 30 microseconds (Fig., B) increased the efficiency of fusion almost equally to the variant of $20 \mathrm{~V}$ - respectively, by 47,$5 ; 44,4 ; 57,4 \%(\mathrm{p}<0,001)$.

It's notable that, even despite the increase in rate of fusion, longer duration of a single impulse (Fig. C) was less efficient than two consecutive shorter impulses (Fig. B). The impact of $25 \mathrm{~V} / 30$ microseconds resulted in, respectively, 35,8 (p $<0,001)$ and $21,3 \%(\mathrm{p}<0,001)$ lower outcome of hybrids than the variants of $30 \mathrm{~V} / 15$ microseconds and $35 \mathrm{~V} / 15$ microseconds. 
Using multiple impulses provided higher rate of resulting hybrids than single impulses, regardless of voltage. Thus, in the variants of two successive impulses of $20,25,30,35$, and $40 \mathrm{~V}$, the efficiency of fusion increased by 23,$0 ; 10,1 ; 53,7$ ( $p<0,001$ ); 34,3 $(\mathrm{p}<0,001)$; and 9,3\% compared with results of equal single impulses.

So, blind enucleation ensures complete removal of chromosomes in bovine oocytes with the first polar body deviated from metaphase II by no more than $10^{\circ}$. For enucleated bovine oocyte and embryonic fibroblast, the efficiency of cytoplasm fusion depends on parameters of the applied electric field - its voltage, duration, and multiplicity of impulses. The optimum parameters for electrofusion of these cells in multiporator Eppendorf (Germany) were determined: two successive impulses of direct electric field of $30 \mathrm{~V}$ and duration of 15 microseconds, preceded by the single impulse of alternating electric field with a voltage of $5 \mathrm{~V}$ and duration of 10 seconds. The obtained data allow suggesting the established optimized conditions of electrofusion for the use in further experiments on cloning cattle embryos.

\section{REFERENCES}

1. Prather R.S., Shen M., Dai Y. Genetically modified pigs for medicine and agriculture. Biotechnol. Genet. Eng. Rev., 2008, 25: $245-266$.

2. Farin P.W., Piedrahita J.A., Farin C.E. Errors in development of fetuses and placentas from in vitro-produced bovine embryos. Theriogenology, 2006, 65: 178-191.

3. Bertolini M., Bertolini L.R., Gerger R.P.C., Batchelder C.A. et al. Developmental problems during pregnancy after in vitro embryo manipulations. Rev. Bras. Reprod. Anim., 2007, 31:391-405.

4. Parnpai R., Kanokwan Srirattana K., Imsoonthornruksa S., Ketudat-Cairns M. Somatic cell cloning for livestock and endangered species. Thai. J. Vet. Med. Suppl., 2011, 41: 77-85

5. Prather R.S., Tao T., Machaty Z. Development of the techniques for nuclear transfer in pigs. Theriogenology, 1999, 51: 487-498.

6. Forsberg E.J., Strelchenko N.S., Augenstein M.L., Betthauser J.M., Childs L.A., Eilertsen K.J., Enos J.M., Forsythe T.M., Golueke P.J., Koppang R.W., Lange G., Lesmeister T.L., Mallon K.S., Mell G.D., Misica P.M., Pace M.M., Pfister-Genskow M., Voelker G.R., Watt S.R., Bi-shop M.D. Production of cloned cattlefrom in vitro systems. Biol. Reprod., 2002, 6: 327-333.

7. Dominko T., Chan A., Simerly C., Luetjens C.M., Hewitson L., Marti-novich C., Schatten G. Dynamic imaging of the metaphase II spindle and maternal chromosomes in bovine oocytes implications for enucleation efficiency verification, avoidance of parthenogenesis, and successful embryogenesis. Biol. Reprod., 2000, 62: $150-154$.

8. Hua S., Zhang Z., Zhang C., Zhang Y. An improved enucleation method of bovine somatic cell nuclear transfer. J. Gen. Genomics, $2007,34(6)$ : 491-496.

9. Jeon B.-G., Betts D.H., King W.A., Rho G.-J. In vitro developmental potential of nuclear transfer embryos cloned with enucleation methods using pre-denuded bovine oocytes. Reprod. Dom. Anim., 2011, 46(6): 1035-1042.

10. Jang G., Oh H.J., Kim M.K., Fibrianto Y.H., Hossein M.S., Kim H.J., Kim J.J., Hong S.G., Park J.E., Kang S.K., Lee B.C. Improvement of canine somatic cell nuclear transfer procedure. Teriogenology, 2008, 69(2): 146-154.

11. Lee E., Estrada J., Piedrahita J. Comparative study on the efficiency of two enucleation methods in pig somatic cell nuclear transfer: effects of the squeezing and the aspiration methods. Anim. Biotechnol., 2008, 19(2): 71-79.

12. Popova E., Bader M., Krivokharchenko A. Efficient production of nuclear transferred rat embryos by modified methods of reconstruction. Mol. Reprod. Dev., 2009, 76: $208-216$.

13. Kim S.J., Saadeldin I.M., Choi W.J., Lee S.J., Lee W.W., Kim B.H., Han H.J., Bang D.H. Production of transgenic bovine cloned embryos using piggybac transposition. J. Vet. Med. Sci., 2011, 73(11): 1453-1457.

14. Kirienko K.V., Loginov A.G., Algulyan A.S., Smetanina I.G., Tatarinova L.V., Ryabykh V.P. Sel'skokhozyaistvennaya Biologiya [Agricultural Biology], 2007, 4: 53-61.

15. Zimmermann U., Neil G.A. Electromanipulation of cells. NY, CRC Press, 1996.

16. Singina G.N., Ovchinnikov A.A., Taradainik T.E., Zinov'eva N.A., Lopukhov A.V. Agrarnyi vestnik Urala, 2011, 11: 9-10.

17. Rozenkrans C.F., First N.L. Effect of free amino acids and vitamins on cleavage and developmental rate of bovine zygotes in vitro. J. Anim. Science, 1994, 72(2): 434-437. 